\title{
Has the expansion of higher education lead to greater economic growth?
}

\section{Craig Holmes}

This is the Author's Accepted Version of an article published in National Institute Economic Review, May 2013, vol. 224, no. 1, R29-R47, available online at: http://ner.sagepub.com/content/224/1/R29.abstract

\begin{abstract}
There is an enduring belief by UK policymakers that a large higher education sector is an important driver of long-run economic growth, which has been part of the narrative since the Robbins Report. Back then, there was plenty of conjecture and assumption, but strikingly little concrete evidence to support such a belief. This paper asks whether the evidence base has strengthened in the 50 years since it was published. It looks at a number of different growth equation specifications and using international education data, attempts to draw out the contribution of both the number of, and the growth in, graduates since the 1960s. There are three main findings. Firstly, many growth relationships, including those estimated elsewhere in the literature, are quite sensitive to the countries included - which often depends on the variables used - and time period of analysis. I argue that given these issues, growth equations should always be treated with caution. Secondly, neither the increase nor the initial level of higher education has any significant relationship with growth rates both in the OECD and worldwide. This result is robust to numerous different specifications. Thirdly, there is some evidence, consistent with the existing literature, that levels of technical skills at the end of compulsory education matter. The employment of higher level technical skills (proxied by the number of employed researchers in an economy) is also a strong predictor of growth. This gives a possible mechanism linking the output of (some) of the higher education sector with economic growth. However, it does not imply that mass higher education necessarily leads to higher growth. This depends on the skills produced by an expanding tertiary sector and their utilization (or underutilization) in the jobs available to increasing numbers of graduates.
\end{abstract}




\section{1}

\section{Introduction}

There is an enduring belief by UK policymakers that a large higher education sector is an important driver of long-run economic growth. The rapid increase in participation rates throughout the 1990s was in part related to the idea that meeting the rising demands for skills and knowledge caused by technological progress would be key to economic success. Prior to its 2004 higher education reforms, the previous Labour government stated that

"there is compelling evidence that education increases productivity, and moreover that higher education is the most important phase of education for economic growth in developed countries, with increases in HE found to be positively and significantly related to per capita income growth." (DES, 2004, pg. 58)

The present Coalition government has scrapped Labour's 50\% participation target, but has in no way indicated it believes that the sector is any less important for achieving growth. This was emphasised in the Browne Review - "Higher education helps to produce economic growth, which in turn contributes to national prosperity" (Browne Review, 2010, pg. 14) and in policy documents produced in support of the 2011 funding reforms:

"Higher Education is important to growth through equipping individuals with skills that enhance their productivity in the workplace, promoting the economy's knowledge base and driving innovation" (BIS, 2011, pg 21).

The roots of this belief can be seen as far back as the 1963 Robbins Report. One conclusion made by the Committee was that by looking at comparisons with other developed countries, the UK could experience a decline in its standing if it failed to increase the number of university-educated workers in the labour force:

"in modern societies the skills and the versatilities required are increasingly those conferred by higher education. Indeed, unless this country is prepared to expand higher education on something like the scale we recommend, continued economic growth on the scale of the targets set by the National Economic Development Council is, in our view, unlikely to be attainable." (Robbins Report, p. 73)

However, while the correlation between higher education and development are clear ("The communities that have paid most attention to higher studies have in general been the most obviously progressive in respect of income and wealth.”) the Report also notes that "[u]nfortunately - or at least unfortunately for our present purposes - the increase in productivity arising from an 
increase in educational expenditure does not lend itself to easy measurement" and consequently causal connections rest largely on reasoned conjecture.

For example:

"it is probably just at the higher level that the external effects most relevant to growth are of the greatest consequence. The capacity for systematic invention, the capacity readily to perceive and apply the results of scientific progress, and the capacity for leadership both in the fields of organisation and in the transmission and the sifting of ideas - such capacities, if they do not come solely from education at the higher stages, certainly derive in a large measure from the existence of a sufficient proportion of persons educated to this level and of institutions devoted to higher education and research.” (Robbins Report, p. 206)

This paper asks whether the evidence base for the supposed connection between higher education and economic growth has been strengthened substantially since the 1960s to justify the claims made by policymakers. Looking at evidence in recent policy documents, it is not immediately obvious that it has. The most obvious problem is that while there any many studies on education and growth, the availability of good quality data has meant that few have focused specifically on higher education. In providing evidence for the Dearing Inquiry into higher education, Gemmell (1997) concludes:

"However the cross-section evidence for higher education remains limited; recent results are more encouraging than earlier studies suggested but the robustness of these results is uncertain" (paragraph 3.19)

It does not seem as though a huge number of studies have been conducted since that review, and as a result, many references are now becoming somewhat dated. For example, Gemmell's own analysis of higher education and growth between 1960 and 1985 (Gemmell, 1996) is also the main supporting reference in both the DES (2004) and BIS (2011), despite huge growth and change in the sector since the 1980 s. ${ }^{1}$

One exception here is Wolff (2001), who, amongst a wide range of estimations, finds relationship between university enrolment rates and growth between 1950 and 1990, and between the change in enrolment rates and growth between 1960 and 1990. However, he also argues that any effect enrolment rates are probably biased upwards due to reverse causality -

\footnotetext{
${ }^{1}$ DES (2004) explicitly refers to the literature review by Sianesi and Van Reenen (2003). However, the sections of this review which deal with tertiary education largely draw on Gemmell (1996).
} 
rising incomes encourage more people to go to university. Moreover, he found little effect of the higher education attainment of the current workforce (rather than the enrolment rate of the future workforce) on growth, but did find. He concludes for growth "a certain threshold of schooling is required, but once beyond this level of social capability, additional general education has little marginal return...on measured productivity" (pg. 757).

Given the lack of robust results arising from cross-country comparisons, it is perhaps surprising how strongly the growth-higher education link is often asserted. In this paper, I use the readily available Barro-Lee data on average years of education in the workforce to explain differences in growth rates across both the developed and the developing world. Directed by the theoretical literature, I follow a number of different specifications. These specifications are not new to this paper, and similar approaches are found throughout existing empirical work. I extend these approaches to include variables for primary, secondary and tertiary education separately. I then look across all of these findings to see whether there are any indicators that a larger higher education sector has been associated with faster growth over the last 50 years.

To start, section 2 summarises the main theoretical frameworks for discussing higher education and economic growth, and highlights the key implications arising from these theories. Section 3 sets out the estimated regressions suggested by theory. Section 4 discusses the data used in the regressions and section 5 presents the results. Section 6 discusses these results and offers some conclusions.

\section{$2 \quad$ Higher education and economic growth}

Higher education has at least three potential channels through which to affect economic growth: the accumulation of productive skills and capabilities; the generation of new knowledge through innovation, and enabling quicker adoption of existing cutting-edge technologies.

\subsection{Neoclassical growth}

Human capital theory posits that education increases the productivity of an individual through the creation of skills and capabilities. Therefore, at the national level, a country with a larger human capital stock should have a larger national output than an otherwise identical country with a smaller supply of human capital. Mankiw, Romer and Weil (1992) assume that the 
standard neoclassical production function can be augmented to include the stock of human capital stock in a way similar to the physical capital stock. Hence, output $(\mathrm{Y})$ is defined:

$$
Y=A K^{\alpha} L^{\beta} H^{\gamma}
$$

where $\alpha+\beta+\gamma=1, \mathrm{~K}$ is physical capital, $\mathrm{H}$ is human capital ${ }^{2}$, $\mathrm{L}$ is the labour force and $\mathrm{A}$ is total factor productivity, which captures (amongst other features) the available level of technology. From this, economic growth follows from (1) accumulation of both sorts of capital and (2) increases in technology, as in Solow's (1956) growth model, except that there are two accumulation processes for each sort of capital. Investment adds to the capital stock (per worker) if it exceeds the replacement demand that arises following population growth and depreciation (e.g. machines wearing out, skills becoming outdated). Investment is assumed to be a fixed proportion of output (based on a constant saving rate). However, because there are diminishing returns to capital, but replacement demand is proportional to the capital stock, then as the economy grows, investment becomes increasingly used to maintain capital stocks per worker, and less is used to increase stocks. Eventually, the economy reaches a steady state where all investment is used to maintain the existing level of capital per worker.

Therefore, long-run growth does not depend on investments in physical or human capital. Increasing the investment rate in human capital (for example, by diverting more national resources into the provision of university education) creates a short-term increase in growth rates until the new steady state is reached. For instance, when newly qualified university graduates are replacing equally well educate retirees, the human capital stock will reach its steady state and growth returns to its long-run trend (driven by exogenous increases in technology). However, if university education adds to the human capital stock, we should observed an increase in growth over a relatively lengthy period while new graduates replace less well educated retirees.

Empirical approaches which test this model tend to come in two forms. Firstly, there are the growth accounting approaches which breakdown observed growth into that which can be attributed to increases in the productive factors (through investment and human capital accumulation). Secondly, the approach of Mankiw, Romer and Weil analyses the dynamics of growth as convergence towards a common underlying rate driven by technological

\footnotetext{
${ }^{2}$ As $\mathrm{H}$ is a stock variable, it can be thought of as the product of the average level of human capital per worker (call this $h$ ) and the labour force (L), where the former is controlled, at least in part, through the provision of education and training to workers.
} 
progress. Countries that start far away from their steady-state should grow faster as investments lead to more new capital and have much lower replacement requirements. Therefore, growth can be regressed on initial income per capita (or, typically, its natural logarithm) and the factors which determine the steady state: savings rates for physical and human capital, depreciation rates and population growth.

Combining the approaches is problematic from a theoretical perspective. For example, it does not typically make sense to look at how growth might be explained by both initial income level and factor accumulation rates separately, as the countries with low initial income levels are expected to grow faster because they accumulate stocks of capital more quickly. Hence, these two sets of variables are measuring the same thing. There might be an argument for doing so if the level of adopted technology was not common across countries, as is assumed in the Solow model. Initial GDP might then be used to capture differences in the take-up of available technology (or distance from the technological frontier), but this would depend on the countries used in the sample.

\subsection{Higher education and endogenous growth}

In the 1980s, a number of economists proposed models of economic growth which went beyond the Solow model (see Romer, 1994). In Lucas' (1988) model of economic growth and human capital, there are spillovers from human capital accumulation, where more educated workers pass on their knowledge and productive capabilities to other workers. Therefore, the output of an economy shown in Equation (1) can be adjusted as follows to include these spillovers:

$$
Y=A K^{\alpha} L^{\beta} H^{\gamma} h^{\delta}
$$

where $\delta<1$. Suppose, for simplicity, that $\delta=\beta$. Then, output per capita would then be given as:

$$
\frac{Y}{L}=A\left(\frac{K}{L}\right)^{\alpha} h^{1-\alpha}
$$

where $h=H / L$. This means that, instead of diminishing returns, the production function now exhibits constant returns to factors that can be accumulated per worker - if human capital and physical capital per worker doubles, then output per worker also doubles. Saving and investment per worker would increase at the same rate, meaning that the shares of investment 
used for replacement and new capital remain constant and there is no steady state level. Therefore, if we redefine as a measure of the broad stock of capital (both physical and human), then the production function becomes:

$$
\frac{Y}{L}=A \hat{k}
$$

This demonstrates why these models became known as endogenous growth theories - the rate of growth is generated within the model by the accumulation of factors of production. Increasing the stock of these factors generates higher incomes, which leads to more investment, which again leads to higher incomes, and so on. Therefore, the long-run growth rate of the economy will be the rate at which this broad measure of capital grows.

The second important feature of this model is how human capital is accumulated. In the Lucas (1988) model, the human capital growth rate is proportionate to the fraction of time spent in education and training activities, so that:

$$
\frac{\dot{h}}{h}=\theta s
$$

where $0<s<1$ is the proportion of total working time spent studying and training, and $\theta$ is a parameter which captures the maximum growth rate if all time was allocated to education. The implication of this equation is that human capital can increase in perpetuity. An increase in time spent studying permanently adds to the human capital stock, even when the individuals who have received this additional education are no longer working. In essence, new generations "inherit" the human capital of the retiring generation, and add to it as they themselves pass through education and training. Human capital in this model has the characteristics of a non-rival good (and could be thought of more like knowledge than particular learned skills), which has implications for how we think about the effects of increasing the number of university graduates. For example, an English student likely starts their studies from a similar point as earlier generations and may go through a similar learning process during the duration of the course. Similarly, more vocationally-focused higher education courses teach similar sets of skills over time, updated only by changes in technology and procedures.

Notice that both the neoclassical model and the Lucas model feature growth driven by the accumulation of the factors of production - increasing resources dedicated to the production 
of capital (such as an expansion of higher education) creates extra growth. The key differences - non-rival human capital stocks and no steady state - mean that there should be no convergence in the Lucas model, so accumulation affects the long-run growth rate and there should be no negative relationship with initial GDP, providing differences in initial capital and technology take-up are controlled for.

\subsection{Innovation and adoption of new technologies}

The role of knowledge and non-rival human capital is also emphasised in Romer's (1986) model of endogenous growth. In this model, the spillovers which remove the existence of a steady state - leading to a production function similar to that in equation (4) - arise from the investment in physical capital. These investments create new knowledge which can be shared amongst firms who haven't made the same physical capital investments. So, for example, installing a new piece of machinery in a factory generates new skills as workers use it and knowledge about how to produce a particular good more efficiently. Therefore, ensuring individuals are suitably equipped to absorb this knowledge in the work place should lead to higher growth rates. Consequently, numerous authors have placed an emphasis on mathematical and scientific skills as being key to linking schooling with long-run economic growth (see Hanushek and Kimko, 2000). Although such skills can be developed in a number of ways, an increase through higher education would, holding everything else constant, lead to more growth.

In other endogenous growth models (Romer 1990, Jones 1999), knowledge is explicitly linked to research and development activities (R\&D), and long-run growth rates depend on the output of this sector. These models also generate growth endogenously, as investment in $R \& D$ increases the stock of knowledge, which helps facilitate further advances in a way similar to the human capital accumulation relationship described in equation $(5) .{ }^{3}$ Higher

\footnotetext{
${ }^{3}$ The predicted relationships between characteristics of the research sector and growth differ across models, given different underlying assumptions. Romer's (1990) model implies that economic growth is proportional to the stock of human capital engaged in $R \& D$ (rather than changes in the stock). This has some problematic implications, as it suggests that, holding everything else constant (including the share of resources allocated towards research), larger countries should grow faster. It also implies that growth rates should be continually accelerating in countries with population growth, which is not observed in real life. Introducing diminishing returns to the existing stock of knowledge the R\&D production function (Jones 1995) removes this prediction and suggests long-run economic growth depends solely on the growth rate of the number of workers engaged in R\&D. Consequently, policy levers, such as an increase in the resources allocated towards research, only have short-term effects, as diminishing returns to knowledge also have a diminishing contribution to economic growth rates. Similarly, multi-sector models (e.g. Young, 1998), where economic growth leads to a widening variety of products, also deal with the scale effects in Romer (1990), but retain the long-run effect of the policy lever (research intensity).
} 
education obviously plays a key role in ensuring there are sufficient workers in the economy with the ability to carry out $R \& D$ (this was noted in the Robbins Report, quoted in the Introduction).

If the link between higher education and economic growth is seen through the mechanisms of innovating and adoption, then the implication is that countries with higher initial levels of education should grow faster, either because they will have larger $R \& D$ sectors which place the country on a higher growth path, or because they adopt new technologies at a faster rate and remain closer to the technological frontier.

\section{$3 \quad$ Estimation}

In the remainder of this paper, I estimate a series of models derived from the theory discussed above using OLS regression. The aim here is to find any consistent results across numerous different specifications which link higher education to economic growth. The models examine, in turn: (1) convergence to a steady state; (2) accumulation of human capital; (3) initial differences in human capital; (4) differences in educational quality, skills and research intensity.

\subsection{Steady state convergence}

The first set of regression builds up Mankiw, Romer and Weil's (1992) estimation of convergence to a conditional steady state, as predicted by a neoclassical type model. In this model, the steady state depends on the saving rates which drive investment in physical and human capital. Higher saving rates, for a given initial level of GDP, imply faster growth. The growth equation I estimate is ${ }^{4}$ :

$$
\frac{\dot{y}}{y}=a+\varphi_{\mathrm{k}} \ln s_{k}+\varphi_{\mathrm{h}} \ln s_{h}-\lambda \ln y_{1966}
$$

where $y_{1966}$ is the initial level of GDP per capita in 1966. As in Mankiw, Romer and Weil, I distinguish between saving rate for investment ( $s_{k}$, proxied by investment share of GDP) from $s_{h}$, the saving rate for human capital accumulation, or the share of national resources put aside for investing in education in any given year. ${ }^{5}$ I use enrolment rates for primary, secondary

\footnotetext{
Jones (1999) provides a good summary of each class of model.

${ }^{4}$ See Mankiw, Romer and Weil (1992), equation (16) for the full derivation.

5 The original Solow model assumed a closed economy, so that the saving rate and investment rate could be equated, as I do in this estimation. In an open economy, the saving rate may be different to the investment rate
} 
and tertiary education as a proxy for this. The constant term captures the effects on steady state growth of depreciation, population growth and exogenous total factor productivity (TFP) growth. For simplicity in our estimation, I assume that these variables are exogenous and uncorrelated with the saving rate or initial level of GDP.

\subsection{Accumulation}

An alternative way of accounting for growth in the neoclassical model is to look at changes in the stock of the factors of production. In particular, the production function in equation (1) can be expressed in log-linear terms, and then differentiated with respect to time. Hence:

$$
\frac{\dot{y}}{y}=\frac{\dot{A}}{A}+\alpha \frac{\dot{k}}{k}+\gamma \frac{\dot{h}}{h}
$$

Equation (7) can be easily estimated using OLS. If we first assume human capital is rival and relates (exponentially) to schooling years, then the final term in equation (6) is the absolute change in the average years of schooling, $s$, rather than its growth rate:

$$
\frac{\dot{y}}{y}=\frac{\dot{A}}{A}+\alpha \frac{\dot{k}}{k}+\gamma \frac{d s}{d t}
$$

Estimation of equation (8) takes the growth of total factor productivity $A$ as constant across all countries.

\subsection{Levels of schooling}

The endogenous growth theories outlined suggest that convergence might not occur and that total factor productivity growth may vary across countries depending on other factors. In the Lucas model, growth in human capital depends on the level of schooling (see equation 5). In equilibrium, capital grows at the same rate. Therefore, equation (7) reduces down to:

$$
\frac{\dot{y}}{y}=\frac{\dot{A}}{A}+\theta s
$$

I follow Hanushek and Woessmann (2007), who include initial GDP in their estimate equation (7'). The initial output variable potentially captures the original distance from the technological frontier, as countries with greater capacity for catching up should grow faster. The measure might also capture differences in capital stock.

when there are international capital flows. Following Mankiw, Romer and Weil, and given the data that is available, the assumption made in this analysis is that the investment share of GDP is an unbiased proxy of the equilibrium saving rate. 
I then extend this estimation in three ways. Firstly, I regress growth rates in a more general model that includes both increases in years of education and initial levels of education. One way of interpreting this estimation is as a test of neoclassical and endogenous growth theories (see Lindahl and Krueger, 2001). It is also consistent with an endogenous growth model where countries were not at equilibrium initially. I also relax the equilibrium assumption that physical and human capital grow at the same rate and include both separately in the estimation.

Secondly, I control for differences in the quality of schooling. Measuring the variable $s$ simply by the quantity of education assumes that its quality is identical. Differences in the quality, or skills, of students should matter in these models. Greater levels of skills allow, for example, for the quicker adoption of new technology or the generation of new ideas. Again following the approach of Hanushek and Woessmann (2007), I re-estimate equation (7) and control for differences in quality related educational outputs using international test data.

Finally, quality and skill measures using data from international tests such as PISA does not allow us to look at the impact of the quality of higher education on growth as international tests are conducted for pre-16 year old students. There are, to my knowledge, no internationally comparable tests for tertiary students. One indicator of higher education quality is if university graduates end up working in jobs which absolutely require high level technical skills. As discussed in section 2, endogenous growth theories have emphasised R\&D activities as a way of generating technological progress and long-run growth - a larger research sector leads to higher long-run growth rates. In addition, some of technical skills produced through higher education that are needed to work in high end research would also be available to other sectors, leading to faster growth through higher productivity and quicker adapation of new technologies. Therefore, I use a measure of the number of individuals employed as researchers as a proxy for the supply of high level technical skills. This measure is then included in a re-estimate of equation (7).

\section{$4 \quad$ Data}

For the purposes of estimating the above sets of growth equations, I use the available World Bank data. My main dependent variable is the annualised growth rate of real per capita GDP between 1966 and 2006. Per capita GDP is given in constant \$US, using the year 2000 as the base. Growth rates for each country are given in column 1 of Table A.1, in the Appendix. 
Some studies use shorter time periods to measure growth - these studies have a larger number of observations and may be better at capturing the effects of structural and policy shifts during the time period being studied. However, they are also more susceptible to demand side fluctuations. Figure A.1 illustrates how fluctuations in demand affect shorterterm measures of growth rates for a selection of countries.

The gross enrolment ratio at primary, secondary and tertiary levels is taken from UNESCO data for 2006. Investment shares of GDP are taken directly from World Bank national accounts data. For the saving rate for physical capital during the time period of interest, I calculate the average investment share between 1976 and 2006. I multiply investment shares of GDP by per capita GDP to give per capita investment.

To calculate the growth rate of capital, I assume investment in 1966 represents a good proxy for all prior investment and define initial capital stock as the sum of these investments, depreciated at a constant rate, $\delta^{6}$ :

$$
k_{1966}=\frac{I_{1965}}{\delta}
$$

The growth rate of capital is equal to total investment during the time period over the initial capital stock. I capture this as the ratio of current investment rate, as a proxy for investment during the period, to the initial investment rate, which from equation (9) is proportional to the initial capital stock. The depreciation term is picked up in the coefficient in the regression.

For educational attainment data, I largely rely on the most recent Barro-Lee dataset which is readily available. Barro and Lee (2010) have compiled international data on mean years of schooling, amongst other variables, every five years from 1960. For initial levels of education, I use available data in 1965. Factor accumulation measures look at increases between 1965 and 2005. I take advantage of the decomposition of years of schooling into primary, secondary and tertiary education to investigate non-linearities in the relationship between more education and economic growth. Table 4.1 shows the descriptive statistics. Individual country measures are given in the appendix (Table A.1, Columns 2 to 7 )

\footnotetext{
${ }^{6}$ Depreciation is assumed to be an identical rate across all countries.
} 


\begin{tabular}{lccccc}
\hline & $\mathrm{N}$ & Mean & s.d. & Min & Max \\
\cline { 2 - 6 } Years of schooling, 1965 & 91 & 3.68 & 2.53 & 0.27 & 10.04 \\
Years of schooling, primary, 1965 & 91 & 2.83 & 1.85 & 0.17 & 7.06 \\
Years of schooling, secondary, 1965 & 91 & 0.77 & 0.77 & 0.04 & 3.92 \\
Years of schooling, tertiary, 1965 & 90 & 0.08 & 0.11 & 0.00 & 0.55 \\
Change in years of schooling, 1965-2005 & 91 & 3.86 & 1.21 & 1.14 & 7.71 \\
Change in years of schooling, primary, 1965-2005 & 91 & 1.83 & 1.01 & -0.30 & 4.64 \\
Change in years of schooling, secondary 1965-2005 & 91 & 1.76 & 0.87 & 0.28 & 4.03 \\
Change in years of schooling, tertiary, 1965-2005 & 90 & 0.28 & 0.24 & -0.04 & 0.95 \\
\hline
\end{tabular}

Table 4.3 shows the means of these variables across different groups of countries. The richest (and faster growing) countries had higher educational levels in the 1960s, although there has been some catch-up by middle income countries since then. The gap between rich and poor in terms of education attainment has widened overall, although gaps in attainment at primary level have narrowed.

\section{Table 4.3: $\quad$ Educational attainment, by country income group}

\begin{tabular}{lccccc}
\hline & $\begin{array}{c}\text { High } \\
\text { income } \\
\text { OECD }\end{array}$ & $\begin{array}{c}\text { High } \\
\text { income } \\
\text { non- } \\
\text { OECD }\end{array}$ & $\begin{array}{c}\text { Upper } \\
\text { middle } \\
\text { income }\end{array}$ & $\begin{array}{c}\text { Lower } \\
\text { middle } \\
\text { income }\end{array}$ & $\begin{array}{c}\text { Low } \\
\text { income }\end{array}$ \\
\cline { 2 - 6 } Years of schooling, 1965 & 6.86 & 5.67 & 3.37 & 2.60 & 1.00 \\
Years of schooling, primary, 1965 & 5.00 & 4.22 & 2.66 & 2.15 & 0.84 \\
Years of schooling, secondary, 1965 & 1.67 & 1.38 & 0.65 & 0.41 & 0.14 \\
Years of schooling, tertiary, 1965 & 0.19 & 0.07 & 0.06 & 0.05 & 0.01 \\
Change in years of schooling, 1965-2005 & 3.69 & 3.58 & 4.67 & 3.78 & 3.15 \\
Change in years of schooling, primary, 1965-2005 & 0.69 & 1.40 & 2.33 & 2.22 & 2.16 \\
Change in years of schooling, secondary 1965-2005 & 2.43 & 1.95 & 2.04 & 1.40 & 0.94 \\
Change in years of schooling, tertiary, 1965-2005 & 0.57 & 0.23 & 0.30 & 0.15 & 0.06 \\
\hline
\end{tabular}

Correlations between these variables is given in Table 4.4 for countries with growth data, $\mathrm{n}=90$ ). Levels of education are all positively correlated - this is particularly high for secondary and tertiary education in 1965 . This is discussed further in the analysis section.

Educational quality is proxied using international test score. In particular, I take the mean maths and science PISA score in 2006 as our main measure of quality and the skills level of the workforce. This measure correlates highly $(r=0.94)$ with the one used in Hanushek and Woessman (2007). Finally, the quality and technical skill level of higher education students is proxied here by the number of the number of researchers per million of the population. As noted before, this is a somewhat crude proxy for technical skills, as it might also include 
professional researchers not connected to scientific research (for example, it includes arts and humanities PhDs). For the purpose of this paper, I assume the available data correlates with the underlying supply of higher technical skills.

Table 4.4 Correlation matrix, educational attainment

Years of schooling,

primary, 1965

Years of schooling, secondary, 1965

Years of schooling, tertiary, 1965

Change in years of schooling, primary, 1965-

2005

Change in years of schooling, secondary 1965-2005

Change in years of schooling, tertiary, 1965 2005

\begin{tabular}{|c|c|c|c|c|c|}
\hline $\begin{array}{l}\text { Years of } \\
\text { schooling, } \\
\text { primary, } \\
1965\end{array}$ & $\begin{array}{l}\text { Years of } \\
\text { schooling, } \\
\text { secondary, } \\
1965\end{array}$ & $\begin{array}{l}\text { Years of } \\
\text { schooling, } \\
\text { tertiary, } \\
1965\end{array}$ & $\begin{array}{l}\text { Change in } \\
\text { years of } \\
\text { schooling, } \\
\text { primary, } \\
\text { 1965-2005 }\end{array}$ & $\begin{array}{l}\text { Change in } \\
\text { years of } \\
\text { schooling, } \\
\text { secondary } \\
1965-2005\end{array}$ & $\begin{array}{l}\text { Change in } \\
\text { years of } \\
\text { schooling, } \\
\text { tertiary, }\end{array}$ \\
\hline
\end{tabular}

$0.706 \quad 1.000$

$\begin{array}{lll}0.643 & 0.884 & 1.000\end{array}$

$\begin{array}{llll}-0.692 & -0.586 & -0.517 & 1.000\end{array}$

$\begin{array}{lllll}0.445 & 0.303 & 0.171 & -0.190 & 1.000\end{array}$

$\begin{array}{llllll}0.609 & 0.694 & 0.656 & -0.450 & 0.517 & 1.000\end{array}$

Table 4.5 shows the correlation matrix for the 29 countries with the skill measures. PISA scores and researchers have a strong positive correlation.

Table 4.5: Correlation matrix, educational attainment and quality

Years of

Years of
schooling,
primary, 1965

schooling,

primary, 1965

1.000

Years of

schooling,

secondary, 1965

0.479

1.000

Years of

schooling,

tertiary, 1965

PISA 2006

scores

0.504

0.628

0.605

Number of

researchers
Years of

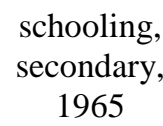

1965

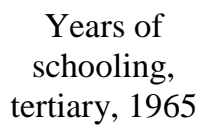

PISA 2006

scores

Number of researchers, per million

population 


\section{$5 \quad$ Results}

\subsection{Convergence}

First, I estimate a number of specifications for equation (6), shown in Table 5.1. In column (1) I estimate the convergence relationship for a classic Solow model which is not augmented to include human capital. The predictive power is significantly improved when enrolment rates are included. Column (2) follows Mankiw, Romer and Weil and includes only enrolment at the secondary level, which is a strongly significantly predictor of the conditional steady state. Finally, column (3) includes all three enrolment rates. This estimation shows that Mankiw, Romer and Weil's original specification was well chosen - both primary and tertiary enrolment rates do not have a significant effect on growth in this model. ${ }^{7}$

Table 5.1: Steady state convergence

\begin{tabular}{llll}
\hline & $(1)$ & $(2)$ & $(3)$ \\
\cline { 2 - 4 } $\ln$ (Initial GDP/capita) & $-0.0036^{*}$ & $-0.0042 * * *$ & $-0.0061^{* * *}$ \\
$\ln ($ Investment/GDP) & $(0.054)$ & $(0.009)$ & $(0.003)$ \\
& $0.0308 * * *$ & $0.0284 * * *$ & $0.0203 * *$ \\
$\ln$ (Primary enrolment rate) & $(0.005)$ & $(0.000)$ & $(0.024)$ \\
& & & -0.0142 \\
$\ln$ (Secondary enrolment rate) & & & $(0.426)$ \\
& & $0.0171 * * *$ & $0.0206 * * *$ \\
$\ln$ (Tertiary enrolment rate) & & $(0.001)$ & $(0.006)$ \\
& & & 0.0010 \\
Constant & & & $(0.753)$ \\
& -0.0368 & $-0.1069 * * *$ & -0.0176 \\
$\mathrm{~N}$ & $(0.347)$ & $(0.000)$ & $(0.849)$ \\
\hline
\end{tabular}

Source: World Bank. Dependent variable: real GDP growth 1966-2006. Note: *** and *** denote significance at the $90 \%, 95 \%$ and $99 \%$ level respectively. P-values in parentheses.

Wolff's (2001) study of OECD countries estimates a similar model to equation (6), for a smaller sample of countries. When higher education enrolment rates were included as the sole measure of the steady state level of education per worker, a strongly significant and positive

\footnotetext{
${ }^{7}$ There are a number of potential biases in this estimation. As noted in Wolff (2001), causal effects from growth to enrollment may bias the estimate on higher education upwards. Enrollment rates may not take account of the export of higher education. Countries with high enrollment rates, such as the UK and US, tend to have a significant number of overseas students who may not add to their university country's supply of human capital once their studies are complete. This would have a negative bias on enrollment rate effects.
} 
relationship was found. In contrast, my estimation includes enrolment at all three levels together, and finds no relationship between growth and the steady state level of higher education. This is not affected by focusing solely on OECD countries.

\subsection{Growth and factor accumulation}

I next estimate equation (8). Table 5.2 shows these results.

Table 5.2: Economic growth and accumulation of factors

\begin{tabular}{|c|c|c|c|c|}
\hline & $(1)$ & $(2)$ & (3) & (4) \\
\hline Change in average years of schooling & $\begin{array}{l}0.005^{* * *} \\
(0.001)\end{array}$ & $\begin{array}{l}0.003^{* *} \\
(0.031)\end{array}$ & & \\
\hline Change in average years of schooling, primary & & & $\begin{array}{l}0.001 \\
(0.406)\end{array}$ & $\begin{array}{l}-0.000 \\
(0.946)\end{array}$ \\
\hline Change in average years of schooling, secondary & & & $\begin{array}{l}0.008 * * * \\
(0.000)\end{array}$ & $\begin{array}{l}0.005^{* * *} \\
(0.001)\end{array}$ \\
\hline Change in average years of schooling, tertiary & & & $\begin{array}{l}0.013 \\
(0.129)\end{array}$ & $\begin{array}{l}0.012^{*} \\
(0.057)\end{array}$ \\
\hline Growth rate of capital & & $\begin{array}{l}0.003 * * * \\
(0.000)\end{array}$ & & $\begin{array}{l}0.003 * * * \\
(0.000)\end{array}$ \\
\hline Constant & $\begin{array}{l}0.002 \\
(0.768)\end{array}$ & $\begin{array}{l}0.001 \\
(0.118)\end{array}$ & $\begin{array}{l}-0.003 \\
(0.621)\end{array}$ & $\begin{array}{l}-0.004 \\
(0.403)\end{array}$ \\
\hline $\mathrm{N}$ & 91 & 60 & 90 & 60 \\
\hline $\mathrm{R}^{2}$ & 0.126 & 0.606 & 0.254 & 0.718 \\
\hline
\end{tabular}

Source: World Bank. Dependent variable: real GDP growth 1966-2006. Note: *,** and *** denote significance at the $90 \%, 95 \%$ and $99 \%$ level respectively. P-values in parentheses.

The estimation in column (1) shows a significant relationship between the growth and changes in average years of schooling of the workforce over the time period. The estimation suggests that an increase of one year in average schooling corresponds to a $0.2 \%$ increase in the growth rate. Controlling for the growth in the capital stock over the same period lowers this estimate, but finds it is still significantly related to growth. The estimations in columns (3) and (4) break down average years of schooling into primary, secondary and tertiary education. The results show that the increase in schooling effect on growth can be clearly attributed to secondary education, with a somewhat less clear contribution coming from the increase in tertiary education - the estimate becomes significant at the $90 \%$ level once the growth rate of capital is accounted for. Increases in primary have no effect on growth rates over the past 40 years. 


\subsection{Growth and initial schooling}

I now estimate equation ( $\left.7^{\prime}\right)$ to explore the relationship predicted by endogenous growth theories between real economic growth and measures of human capital. Initially, I look at quantity measures of schooling, using average years of schooling at the start of the period, and focus only on OECD countries. I compare my results with Hanushek and Woessmann (2007) who use the same educational data to look at growth between 1960 and 2000. The results are reported in Table 5.3:

Table 5.3: Economic growth and schooling in the OECD

\begin{tabular}{lllll}
\hline & \multicolumn{3}{c}{ All available OECD data } & \multicolumn{2}{c}{ OECD countries in both } \\
& $1960-2000$ & $1966-2006$ & $1960-2000$ & $1966-2006$ \\
\cline { 2 - 5 } Initial GDP/capita & $-0.0029^{* * *}$ & -0.0009 & $-0.0031^{* * *}$ & $-0.0016^{* *}$ \\
& $(0.000)$ & $(0.000)$ & $(0.000)$ & $(0.017)$ \\
Initial years of schooling & $0.0017^{*}$ & 0.0006 & $0.0023^{* *}$ & 0.0020 \\
& $(0.051)$ & $(0.566)$ & $(0.028)$ & $(0.143)$ \\
Constant & $0.0399^{* * *}$ & $0.0060^{* * *}$ & $0.0383^{* * *}$ & $0.0285^{* * *}$ \\
& $(0.000)$ & $(0.034)$ & $(0.000)$ & $(0.000)$ \\
$\mathrm{N}$ & 24 & 24 & 21 & 21 \\
$\mathrm{R}^{2}$ & 0.596 & 0.166 & 0.549 & 0.310 \\
\hline
\end{tabular}

Source: Hanushek and Woessmann (2007), World Bank data. Dependent variable: real GDP growth 1966-2006. Clumns (1) and (3) use GDP growth from 1960-2000 and columns (2) and (4) use GDP growth from 1966-2006 Note: GDP/capita is measured in 1000s. *, ** and *** denote significance at the $90 \%, 95 \%$ and $99 \%$ level respectively. P-values in parentheses.

The table shows strikingly different results between the two datasets. Looking at the first two columns, years of schooling in 1960 enters positively into the growth equation, while years of schooling in 1966 does not. Both measures are highly correlated $(r=0.98)$, so it is not so much the quality of the explanatory variable as it is the robustness of the relationship which we should question.

One potential explanation is that the countries included in the two regressions are different. Hanushek and Woessmann's data looked at 24 OECD countries, as does our data taken from the World Bank. However, there is not a perfect overlap between the two datasets - there are three countries in each data set that are not represented in the other. To investigate the role of particular outliers found in one dataset rather than the other I restrict the estimation to countries which are common to both datasets. The final two columns show the results, and indicates that the above conclusion continues to hold (the p-value on the initial schooling 
term falls to 0.14 but remains outside of significance at the $10 \%$ level). The results suggest that growth and education regression results are sensitive to the selection of time period.

Next, I use the breakdown of the Barro-Lee education data into primary, secondary and tertiary education to establish whether this average years of schooling measure has nonlinearities that correspond to the level of education. Table 5.4 shows the results.

Table 5.4 Economic growth and types of schooling in the OECD

\begin{tabular}{lccc}
\hline & $(1)$ & $(2)$ & $(3)$ \\
\cline { 2 - 3 } Initial GDP/capita & $-0.0019 * * *$ & $-0.0019^{* * *}$ & $-0.0018^{* * *}$ \\
Initial years of schooling, primary & $(0.007)$ & $(0.008)$ & $(0.010)$ \\
& $0.0044^{* *}$ & $0.0042^{* *}$ & $0.0044^{* *}$ \\
Initial years of schooling, secondary & $(0.044)$ & $(0.053)$ & $(0.042)$ \\
& 0.0044 & 0.0003 & $(0.900)$ \\
Initial years of schooling, tertiary & $(0.283)$ & & -0.0068 \\
& -0.0289 & & $(0.698)$ \\
Constant & $(0.237)$ & $0.0236 * * *$ & $0.0231 * * *$ \\
& $0.0217 * * *$ & $(0.001)$ & $(0.001)$ \\
\hline $\mathrm{N}$ & $(0.003)$ & 21 & 21 \\
$\mathrm{R}^{2}$ & 21 & 0.384 & 0.394 \\
\hline
\end{tabular}

Source: World Bank data. Dependent variable: real GDP growth 1966-2006. Note: GDP/capita is measured in 1000s. *, ** and *** denote significance at the $90 \%, 95 \%$ and $99 \%$ level respectively. P-values in parentheses.

In section $4 \mathrm{I}$ noted that secondary and tertiary education are highly correlated $(\mathrm{r}=0.89)$. Columns (2) and (3) show that removing one or the other variable does not alter the results, meaning the lack of significance does not appear to be attributable to collinearity between secondary and tertiary education. ${ }^{8}$

I extend the above analysis to include all the available countries in the dataset, as well as distinction between high, middle and low income countries as defined by the World Bank. Table 5.5 shows the results.

Including all 91 countries which have schooling and income data reveals a strongly significant correlation between years of schooling and growth between 1966 and 2006. When broken down by level of education, this correlation remains positive and significant for initial

\footnotetext{
${ }^{8}$ This same approach was taken in all other regression. The results are not presented here - however, no significant relationships were found through performing this check.
} 
levels of primary and secondary schooling, but not significant for years of tertiary education. Looking across different groups of country by income, there are few significant results. This is likely because the level of a countries income is based on current incomes, so there are endogeneity issues - countries that have grown faster and are now richer.

Table 5.5: Economic growth and schooling by country income

\begin{tabular}{|c|c|c|c|c|c|c|c|c|}
\hline & All & $\begin{array}{l}\text { High } \\
\text { income }\end{array}$ & $\begin{array}{l}\text { Middle } \\
\text { income }\end{array}$ & $\begin{array}{c}\text { Low } \\
\text { income }\end{array}$ & All & High income & Middle income & Low income \\
\hline $\begin{array}{l}\text { Initial } \\
\text { GDP/capita }\end{array}$ & $\begin{array}{l}-0.001 \\
(0.124)\end{array}$ & $\begin{array}{r}- \\
0.0009 * * * \\
(0.104)\end{array}$ & $\begin{array}{r}-0.0049^{* *} * \\
(0.013)\end{array}$ & $\begin{array}{r}- \\
0.0517 * * \\
(0.035)\end{array}$ & $\begin{array}{r}-0.0010 \\
(0.129)\end{array}$ & $\begin{array}{r}-0.0010^{*} \\
(0.087)\end{array}$ & $\begin{array}{r}-0.0048^{* *} * \\
(0.02)\end{array}$ & $\begin{array}{r}-0.0517 * \\
(0.094)\end{array}$ \\
\hline Schooling & $\begin{array}{r}0.0039 * * * \\
(0.001)\end{array}$ & $\begin{array}{r}-0.0012 \\
(0.367)\end{array}$ & $\begin{array}{c}0.0021 \\
(0.160)\end{array}$ & $\begin{array}{c}0.0053 \\
(0.343)\end{array}$ & & & & \\
\hline Primary & & & & & $\begin{array}{r}0.0042 * * * \\
(0.004)\end{array}$ & $\begin{array}{r}-0.0023 \\
(0.257)\end{array}$ & $\begin{array}{c}0.0027 \\
(0.217)\end{array}$ & $\begin{array}{c}0.0054 \\
(0.523)\end{array}$ \\
\hline Secondary & & & & & $\begin{array}{r}0.0122^{* *} * \\
(0.031)\end{array}$ & $\begin{array}{c}0.0027 \\
(0.556)\end{array}$ & $\begin{array}{c}0.0032 \\
(0.755)\end{array}$ & $\begin{array}{r}0.0770 \\
(0.262)\end{array}$ \\
\hline Tertiary & & & & & $\begin{array}{r}-0.0657 * \\
(0.057)\end{array}$ & $\begin{array}{r}-0.0142 \\
(0.616)\end{array}$ & $\begin{array}{r}-0.0293 \\
(0.621)\end{array}$ & $\begin{array}{r}-0.4939 \\
(0.339)\end{array}$ \\
\hline Constant & $\begin{array}{r}0.0068 * * \\
(0.034) \\
\end{array}$ & $\begin{array}{r}0.0447 * * * \\
(0.000)\end{array}$ & $\begin{array}{r}0.0191 * * * \\
(0.000)\end{array}$ & $\begin{array}{c}0.0096 \\
(0.285)\end{array}$ & $\begin{array}{r}0.0071 * * \\
(0.034)\end{array}$ & $\begin{array}{r}0.0479 * * * \\
(0.000)\end{array}$ & $\begin{array}{r}0.0186^{* * * *} \\
(0.000)\end{array}$ & $\begin{array}{c}0.0044 \\
(0.711)\end{array}$ \\
\hline $\mathrm{N}$ & 91 & 26 & 49 & 16 & 90 & 26 & 49 & 15 \\
\hline $\mathrm{R}^{2}$ & 0.163 & 0.283 & 0.13 & 0.311 & 0.199 & 0.332 & 0.136 & 0.388 \\
\hline
\end{tabular}

Source: World Bank data. Dependent variable: real GDP growth 1966-2006. Note: GDP/capita is measured in 1000 s. *, ** and *** denote significance at the $90 \%, 95 \%$ and $99 \%$ level respectively. P-values in parentheses.

I next combine both initial level and accumulation effects in a single model. The combined model, shown in Table 5.6, is consistent with previous results - changes in secondary schooling and initial levels of primary schooling are positively associated with growth rates. Controlling for capital growth, as in equation (2) improves the model - when I do this, initial years of secondary education becomes significant at the $90 \%$ level, but years of primary schooling drops out of significance. Critically, neither tertiary education variable has any significant effect on growth. 
Table 5.6: Economic growth and schooling by country income

\begin{tabular}{lll}
\hline & $(1)$ & $(2)$ \\
\cline { 2 - 3 } Change in average years of schooling, primary & $0.0055^{* *}$ & $0.0034^{*}$ \\
Change in average years of schooling, secondary & $(0.016)$ & $(0.089)$ \\
& $\left(0.0287^{* *}\right.$ & $0.0045^{* *}$ \\
Change in average years of schooling, tertiary & 0.0066 & $(0.021)$ \\
& $(0.528)$ & 0.0061 \\
Initial years of schooling, primary & $0.0036^{* *}$ & $(0.400)$ \\
& $(0.020)$ & 0.0020 \\
Initial years of schooling, secondary & 0.0073 & $(0.128)$ \\
& $(0.145)$ & $0.0074 * *$ \\
Initial years of schooling, tertiary & -0.0482 & $(0.038)$ \\
& $(0.157)$ & -0.0341 \\
Growth rate of capital & & $(0.138)$ \\
Constant & & $0.0029^{* * *}$ \\
& & $(0.000)$ \\
$\mathrm{N}$ & $-0.0158^{* *}$ & $-0.0151^{* *}$ \\
\hline
\end{tabular}

Source: World Bank data. Dependent variable: real GDP growth 1966-2006. Note: *,** and *** denote significance at the $90 \%, 95 \%$ and $99 \%$ level respectively. P-values in parentheses.

\subsection{Growth, quality and skills}

Hanushek and Woessmann (2007) show that quantity measures explain little variation in growth rates once differences in quality of education measures are included. In this section I re-estimate equation ( $\left.7^{\prime}\right)$ to include quality measures of human capital differences between countries.

The quality data only captures differences at the level of primary and secondary education. Therefore, the quality measure should not affect the years of tertiary education variable. Indeed, it is possible that controlling more precisely for human capital differences at the primary and secondary level could increase the explanatory power of tertiary education, on the assumption that there is a complementary relationship between the quality of students leaving secondary schooling and the effectiveness of higher education.

Table 5.7 reports the results of this analysis using our growth data. The results show that once quality is controlled for, either via the composite Hanushek and Woessmann (2007) measure 
or a simple PISA average, then none of the years of schooling (to the extent that they mattered before controlling for quality) enter the growth equation in a significant way.

Table 5.7: $\quad$ Economic growth, schooling and quality

\begin{tabular}{|c|c|c|c|c|}
\hline \multirow[b]{2}{*}{ Initial GDP/capita } & \multicolumn{2}{|c|}{ OECD } & \multicolumn{2}{|c|}{ All available } \\
\hline & $-0.0018 * * *$ & $-0.0011 * *$ & $-0.0012 * * *$ & $-0.0016^{* * *}$ \\
\hline & $(0.002)$ & $(0.025)$ & $(0.010)$ & $(0.005)$ \\
\hline \multirow[t]{2}{*}{ Primary } & 0.0020 & 0.0004 & -0.0009 & -0.0005 \\
\hline & $(0.270)$ & $(0.769)$ & $(0.519)$ & $(0.660)$ \\
\hline \multirow[t]{2}{*}{ Secondary } & 0.0012 & 0.0048 & -0.0037 & $0.0064 * *$ \\
\hline & $(0.712)$ & $(0.209)$ & $(0.334)$ & $(0.078)$ \\
\hline \multirow[t]{2}{*}{ Tertiary } & -0.0135 & -0.0345 & -0.0292 & $-0.0409 * *$ \\
\hline & $(0.502)$ & $(0.143)$ & $(0.224)$ & $(0.058)$ \\
\hline \multirow[t]{2}{*}{ HW2007 quality } & $0.0002 * * *$ & & & \\
\hline & $(0.007)$ & & & \\
\hline \multirow[t]{2}{*}{ PISA 2006} & & $0.0001 *$ & $0.0001 * * *$ & $0.0001 * *$ \\
\hline & & $(0.051)$ & $(0.002)$ & $(0.039)$ \\
\hline \multirow[t]{2}{*}{ Researchers } & & & & $0.0019 *$ \\
\hline & & & & $(0.098)$ \\
\hline \multirow[t]{2}{*}{ Constant } & $-0.0412 *$ & -0.0176 & -0.0166 & -0.0090 \\
\hline & $(0.066)$ & $(0.418)$ & $(0.235)$ & $(0.554)$ \\
\hline $\mathrm{N}$ & 21 & 24 & 34 & 29 \\
\hline $\mathrm{R}^{2}$ & 0.659 & 0.417 & 0.430 & 0.600 \\
\hline
\end{tabular}

Source: Hanushek and Woessmann (2007), World Bank data. Dependent variable: real GDP growth 1966-2006. Note: GDP/capita is measured in 1000s. *, ** and *** denote significance at the $90 \%, 95 \%$ and $99 \%$ level respectively. P-values in parentheses.

The final column of Table 5.7 includes the number of researchers per million of the population as a proxy for qualitative differences in outcomes at the tertiary level that have a relevance for economic growth The results show that countries with more researchers have grown more over the past 40 years. Introducing these measures has effects on the contribution of the other variables. Years of tertiary education becomes negatively related to growth, once $\mathrm{R} \& \mathrm{D}$ activity has been taken into account.,Educational quality remains significant, although years of secondary schooling also becomes significant again.

\section{Discussion and conclusions}

The above results fail to find a significant effect of the higher education sector (either through its initial level or its expansion) on economic growth during the past forty years, whereas 
positive and significant relationships are found with primary and secondary education, measures of technical skills, research activity and capital accumulation.

One response to these results would be to argue that there is a relationship between economic growth and higher education, but that despite casting a wide net in an attempt to find some evidence that countries grow faster if they invest more in higher education, the true relationship is not easily drawn out in the regression specifications used above. As I have shown in this paper, estimations are sensitive to the data that is included, both in terms of the countries used and the time period. Moreover, measurement error might be a persistent problem. Although data quality continues to improve with each new set of cross-country comparisons, I can not rule out the possibility that mismeasuring the size and importance of tertiary education sector is not responsible for these results. These are real difficulties in using cross-national data to understand anything about the differences in economic growth. Of course, these same difficulties tend to be ignored when more positive results are discovered, so the most important implication of this analysis is that more caution should be used in this area.

As a result, this paper does not go so far as to argue that higher education does not, or cannot lead to economic growth. What it does argue is that there is a sizeable and worrying gap between what is asserted and what the most readily available evidence has to say when applied to the most standard of approaches. It may come as a surprise to policymakers in the UK and elsewhere that cross-country comparisons fail to show any effect of higher education on growth - as noted in the Browne Review, the OECD contends very strongly that this is precisely what cross-country comparisons do show.

What alternative evidence is there? The lack of robust macroeconomic evidence has sometimes been supplemented with microeconomic analysis. In particular, there is very strong evidence that graudates command a large and significant wage premium over nongraduates (Pscharoupoulos, 2009). If real wages are taken as a proxy for productivity, then this evidence implies graduates are more productive than non-graduates. Moreover, if graduates are more productive than non-graduates, then even without externalities and endogenous growth mechanisms, increases in participation in tertiary education should have lead to higher growth over the past 40 years.

Taken at face value, the results of this paper clearly clash with this line of thinking. As Alison Wolf and others have discussed (see Wolf, 2002) one reason for this might be that having a 
degree acts as a filter for employers recruiting into higher paying jobs. In the traditional signalling model (Spence, 1973), individuals have private information about their own productivity, and use the completion of a degree as to convey this information to employers. However, it is not actually important whether graduates have prior differences in productivity, just that there are a number of jobs which are higher paying and which the employers have a preference for hiring graduates. ${ }^{9}$ The main implication of this model is that while it makes a lot of sense for any individual to pursue higher education in order to be recruited into higher paying jobs (especially if that is what their peers are doing), at the national level this decision should make little difference. A country with a similar structure of occupations and available technology, but far fewer graduates, would have an identical national income and growth performance.

Some recent papers have used more sophisticated econometric techniques than those presented here to find specific channels through which higher education has added to growth. For example, Aghion et al (2009) find that increases in patenting in the US can be attributed to exogenous increases in spending on four-year degree courses at research intensive universities and subsequent economic growth. Vanderbussche et al (2006) find a link between five-year growth rates and higher education once distance from the technological frontier is controlled for, again indicating that higher education plays a role through technological innovation. Similar to my much simpler measure of the supply of high level technical skills, these papers emphasise that the interaction between some high level skills and technology could be important.

However, this does not imply that mass higher education necessarily leads to higher growth. In part, this depends on what skills are being produced as the system grows. This paper does not have adequate data to control for the many differences in higher education, but differences between subject of study and the quality of higher education institutions will matter. What we do know is that as countries like the UK have expanded their higher education system, the sector has become more heterogeneous. The fasting growing subjects tend not to be in technical subjects - leading to repeated claims of shortages of science, technology, engineering and maths (STEM) graduates - but in areas such as creative arts and design, business and administration, psychology, sports science and mass communication. ${ }^{10}$ It

\footnotetext{
${ }^{9}$ This is the key idea behind Lester Thuroweh job queue model (Thurow, 1973).

${ }^{10}$ Based on an analysis of HESA data between 1994/5 and 2010/11 - data shown in Appendix Table A.2.
} 
is less clear how the skills produced on these courses lead to innovation and economic growth.

It is also worth noting that higher education is not the only way to develop the necessary technical skills required to adopt new technology or improve production processes. The expansion of higher education has also lead to the creation of more vocational courses which has meant less young people following apprenticeship pathways. UK labour force data suggests that between 1995 and 2008, the share of apprentices without degrees in employment fell from 15.2\% to 9.1\% - Holmes and Mayhew (2013) estimate that this largely reflects changes in the educational composition of occupations $(5.0 \%)$ rather than the decline in occupations which were dominated by apprentice-trained workers, such as skilled trades $(1.1 \%)$. This shift may come with a cost if those practical or technical skills become depleted in exchange for more general academic knowledge.

Finally, the link between a growing higher education sector and future growth also depends on what work new graduates are able to find when they enter the labour market. Much of the discussion around human capital theory which drives the growth models in section 2 assumes that the demand side of the labour market is either irrelevant or benignly accommodating. If that were the case, then the supply of skills should directly determine the productivity of labour. However, the demand side of the labour market and the distribution of jobs also matters. Taking the UK as an example, the growth of graduate-level jobs has been far slower than the growth in graduates over the past 20 years, leading to many graduates working in non-graduate jobs. The untested assumption is that these graduates will be more productive than the non-graduates they replace, but evidence of upskilling is thin, particularly in the service sector occupations many new graduates enter (Mason, 2002; Keep and Mayhew, 2004). Without an accommodating demand side, improvements in the supply of graduate skills will at best be a necessary, but not sufficient, condition for higher long-run growth. 


\section{References}

Aghion, P, Boustan, L, Hoxby, C, Vandenbussche, J, (2009), The Causal Impact of Education on Economic Growth: Evidence from the United States, accessed online January $5^{\text {th }}$ 2013: http://scholar.harvard.edu/files/causal_impact_of_education_0.pdf

Barro, R, and Lee, J, (2010), A New Data Set of Educational Attainment in the World, 19502010, NBER Working Paper No. 15902.

BIS, (2011), Supporting analysis for the Higher Education White Paper', BIS Economics Paper No. 14.

DES, (2004), The Future of Higher Education.

Gemmell, N, (1996), 'Evaluating the Impacts of Human Capital Stocks and Accumulation on Economic Growth: Some New Evidence,' Oxford Bulletin of Economics and Statistics, 58(1), pp. 9-28.

Gemmell, N, (1997), 'Externalities to higher education: a review of the new growth literature', Report to the National Committee of Inquiry into Higher Education.

Hanuschek, E, and Kimko, D, (2000), 'Schooling, Labour Force Quality, and the Growth of Nations', American Economic Review, 90 pp. 1184-1208

Hanushek, E, and Woessmann, L, (2007), 'The Role of Education Quality for Economic Growth', World Bank Working Paper No. 4122.

Holmes, C, and Mayhew, K, (2013), Are Universities the Best Way to Create High Skills? The Consequences of Mass Higher Education in the UK, conference paper presented at the $31^{\text {st }}$ International Labour Process Conference, Rutgers University, March $20^{\text {th }}$.

Jones, C, (1995), 'R\&D based models of economic growth', Journal of Political Economy, 103(4) pp. 759-84.

Jones, C, (1999), 'Growth: With or Without Scale Effects?', American Economic Review Papers and Proceedings 89, pp. 139-144.

Lindahl and Krueger, A, (2001), 'Education and Growth: Why and For Whom?', Quarterly Journal of Economics, 39(4) pp. 1101-1136. 
Lucas, R, (1988), On the Mechanics of Economic Development, Journal of Monetary Economics 22, pp. 3-42

Keep, E, and Mayhew, K, (2004), The Economic and Distributional Implications of Current Policies on Higher Education', Oxford Review of Economic Policy 20(2), pp. 298-313

Mankiw, G, Romer, D, and Weil, D, (1992), 'A Contribution to the Empirics On Economic Growth', Quarterly Journal of Economics 107, pp. 407-437.

Mason, G, (2002), 'High skills utilisation under mass higher education: Graduate employment in service industries in Britain', Journal of Education and Work 15(4), pp. 427456

Pscharoupoulos, G, (2009), 'Returns to investment in higher education: European Survey - a contribution to the Higher Education Funding Reform Project CHEPS-led consortium for the European Commission'. Accessed online April $4^{\text {th }}$ 2013: http://ec.europa.eu/education/highereducation/doc/funding/vol3_en.pdf

Robbins Report (1963), 'Education in England: Higher Education, http://www.educationengland.org.uk/documents/robbins/index.html.

Romer, P, (1986), 'Increasing Returns and Long Run Economic Growth', Journal of Political Economy 94(5), pp. 1002-1037.

Romer, P, (1990), 'Endogenous Technological Change', Journal of Political Economy 98(5), pp. S71-S102.

Romer, P, (1994), 'The Origins of Endogenous Growth', Journal of Economic Perspectives 8(1), pp. 3-22.

Sianesi, B, and Van Reenan, J, (2003), 'The Returns to Education: Macroeconomics', Journal of Economic Surveys, 17 (2): pp. 157-200.

Spence, M, (1973), 'Job Market Signaling', Quarterly Journal of Economics 87(3): pp. 355374.

Thurow, L, (1976), Generating Inequality, London: Macmillan.

Vandenbussche, J, Aghion, A, and Meghir, C, (2006), Growth, Distance from the Frontier and 
Composition of Human Capital, Journal of Economic Growth 11, pp. 97-107.

Wolf, A, (2002), Does Education Matter?, Penguin.

Wolff, E, (2001), 'Productivity Convergence and Education: Evidence from OECD Countries', Industrial and Corporate Change 10(3): pp 735-759

Young, A, (1998), 'Growth without scale effects', Journal of Political Economy 106(1) pp. 41-63. 


\section{Data appendix}

Unless a specific subsample is specified, all regressions use as many countries as are available from World Bank data. Sample sizes change significantly when certain variables are included, and the paper has attempted to make it clear that the sensitivity of analyses to sample is one reason that growth regressions should always be treated with caution. The below table summarizes which countries were included in each regression. Specific regressions are denoted by the table they appear in followed by the column of the table in parentheses.

\begin{tabular}{|c|c|}
\hline Regression & Countries \\
\hline $5.1(1)$ & $\begin{array}{l}\text { Algeria, Argentina, Australia, Austria, Barbados, Belgium, Bolivia, } \\
\text { Botswana, Brazil, Burundi, Cameroon, Canada, Chile, China, } \\
\text { Colombia, Dem. Rep. of Congo, Rep. of Congo, Costa Rica, Cote } \\
\text { d'Ivoire, Denmark, Dominican Republic, Ecuador, Egypt, El Salvador, } \\
\text { Fiji, Finland, France, Gabon, Ghana, Greece, Guatemala, Guyana, } \\
\text { Honduras, Hong Kong, Hungary, Iceland, India, Iran, Israel, Italy, } \\
\text { Japan, Kenya, Korea, Lesotho, Luxembourg, Madagascar, Malawi, } \\
\text { Malaysia, Mauritania, Mexico, Morocco, Nepal, Netherlands, } \\
\text { Nicaragua, Norway, Pakistan, Papua New Guinea, Paraguay, Peru, } \\
\text { Philippines, Portugal, Rwanda, Senegal, Seychelles, Singapore, South } \\
\text { Africa, Spain, Sri Lanka, Sudan, Sweden, Syria, Thailand, Trinidad and } \\
\text { Tobago, Tunisia, Turkey, United Kingdom, United States, Uruguay, } \\
\text { Venezuela, Zambia, and Zimbabwe. }\end{array}$ \\
\hline $5.1(2)$ & $\begin{array}{l}\text { As } 5.1 \text { (1), except: Algeria, Brazil, Dem. Rep. of Congo, Rep. of } \\
\text { Congo, Cote d'Ivoire, Egypt, Gabon, Guyana, Papua New Guinea, } \\
\text { Seychelles, Singapore, Sri Lanka, Trinidad and Tobago, Zambia, and } \\
\text { Zimbabwe. }\end{array}$ \\
\hline $5.1(3)$ & $\begin{array}{l}\text { As } 5.1 \text { (2), except: Barbados, Bolivia, Canada, Costa Rica, Dominican } \\
\text { Republic, Ecuador, Fiji, Guatemala, Honduras, Kenya, Malaysia, } \\
\text { Nepal, Nicaragua, Paraguay, South Africa, Sudan, Syria, Uruguay and } \\
\text { Venezuela. }\end{array}$ \\
\hline $5.2(1)$ & $\begin{array}{l}\text { As 5.1(1), except: Madagascar and Seychelles, and including: } \\
\text { Bangladesh, Belize, Benin, Central African Republic, Gambia, } \\
\text { Indonesia, Latvia, Liberia, Niger, Panama, Sierra Leone and Togo. }\end{array}$ \\
\hline $5.2(2)$ & $\begin{array}{l}\text { As 5.2(1), except: Algeria, Austria, Bangladesh, Belgium, Belize, } \\
\text { Benin, Bolivia, Brazil, Cameroon, Central African Republic, Rep. of } \\
\text { Congo, France, Gabon, Gambia, Ghana, Indonesia, Latvia, Lesotho, } \\
\text { Liberia, Malawi, Nepal, Netherlands, Niger, Panama, Portugal, Sierra } \\
\text { Leone, Spain, Sudan, Togo, Turkey, and Zambia. }\end{array}$ \\
\hline $5.2(3)$ & As 5.2(1), except: Malawi. \\
\hline $5.2(4)$ & As 5.2(2). \\
\hline $5.3(1)$ & As 5.3 (3), including: Ireland, Switzerland, and New Zealand \\
\hline $5.3(2)$ & As 5.3 (3), including: Hungary, Israel, and Luxembourg. \\
\hline $5.3(3)$ & Australia, Austria, Belgium, Canada, Denmark, Finland, France, \\
\hline
\end{tabular}




\begin{tabular}{|c|c|}
\hline & $\begin{array}{l}\text { Greece, Iceland, Italy, Japan, Korea, Mexico, Netherlands, Norway, } \\
\text { Portugal, Spain, Sweden, Turkey, United Kingdom, and United States. }\end{array}$ \\
\hline $5.3(4)$ & As 5.3 (3). \\
\hline $5.4(1)$ & As 5.3 (3). \\
\hline $5.4(2)$ & As 5.3 (3). \\
\hline $5.4(3)$ & As 5.3 (3). \\
\hline $5.5(1)$ & As $5.2(1)$. \\
\hline $5.5(2)$ & $\begin{array}{l}\text { Australia, Austria, Barbados, Belgium, Canada, Denmark, Finland, } \\
\text { France, Greece, Hong Kong, Hungary, Iceland, Israel, Italy, Japan, } \\
\text { Korea, Luxembourg, Netherlands, Norway, Portugal, Singapore, Spain, } \\
\text { Sweden, Trinidad and Tobago, United Kingdom, and United States. }\end{array}$ \\
\hline $5.5(3)$ & $\begin{array}{l}\text { Algeria, Argentina, Belize, Bolivia, Botswana, Brazil, Cameroon, } \\
\text { Chile, China, Colombia, Rep. of Congo, Costa Rica, Cote d'Ivoire, } \\
\text { Dominican Republic, Ecuador, Egypt, El Salvador, Fiji, Gabon, Ghana, } \\
\text { Guatemala, Guyana, Honduras, India, Indonesia, Iran, Latvia, Lesotho, } \\
\text { Malaysia, Mexico, Morocco, Nicaragua, Pakistan, Panama, Papua New } \\
\text { Guinea, Paraguay, Peru, Philippines, Senegal, South Africa, Sri Lanka, } \\
\text { Sudan, Syrian Arab Republic, Thailand, Tunisia, Turkey, Uruguay, } \\
\text { Venezuela and Zambia }\end{array}$ \\
\hline $5.5(4)$ & $\begin{array}{l}\text { Bangladesh, Benin, Burundi, Central African Republic, Dem Rep. of } \\
\text { Congo, Gambia, Kenya, Liberia, Malawi, Mauritania, Nepal, Niger, } \\
\text { Rwanda, Sierra Leone, Togo, and Zimbabwe. }\end{array}$ \\
\hline $5.5(5)$ & As 5.5(1), except: Malawi. \\
\hline $5.5(6)$ & As $5.5(2)$ \\
\hline $5.5(7)$ & As 5.5 (3) \\
\hline $5.5(8)$ & As 5.5(4), except: Malawi. \\
\hline $5.6(1)$ & As 5.2(2). \\
\hline $5.6(2)$ & As 5.2(2). \\
\hline $5.7(1)$ & As 5.3 (3). \\
\hline $5.7(2)$ & As 5.3 (3), including: Hungary, Israel and Luxembourg \\
\hline $5.7(3)$ & $\begin{array}{l}\text { As } 5.3 \text { (3), including: Argentina, Brazil, Chile, Colombia, Hong Kong, } \\
\text { Hungary, Indonesia, Israel, Latvia, Luxembourg, Thailand, Tunisia, } \\
\text { Uruguay. }\end{array}$ \\
\hline $5.7(4)$ & $\begin{array}{l}\text { As } 5.3 \text { (3), including: Argentina, Brazil, Colombia, Hong Kong, } \\
\text { Hungary, Latvia, Luxembourg, Tunisia. }\end{array}$ \\
\hline
\end{tabular}




\section{Appendix}

Figure A.1 shows shorter-term growth rates over this time period for a few key countries. The three high income, high education countries have the most stable growth rates over the entire time period. However, growth in Sweden is clearly affected by a large demand-side shocks in the early 1990s, followed by a recovery in the late 1990s and 2000s.

Upper middle income countries Singapore and Brazil both had high growth rates in the 1960s, which have subsequently declined. However, the decline in Brazil has been far more pronounced than Singapore (and other East Asian countries such as Hong Kong and Korea)., falling below the long-run growth rates of higher income countries. Again, demand side factors are evident here - first in the build-up of debt during the 1970s, followed by a debt crisis and in the early 1980s and a prolonged period of weak demand, with only a slight recovery in the final period.

Egypt and China both had relatively low growth in the 1960s, considering their scope for technological catch-up. China has undergone huge economic reforms since the 1970s and have had sustained levels of high growth since that point. Egypt's growth has also been affected by a debt crisis in the 1980s. However, in general it would appear that the two countries have very different long-run growth rates. Interestingly, they have both followed very similar policies on education, increasing attainment at all levels. The main difference appears to be in years of primary education at the start of the period, consistent with results found in the main body of this paper. 
Figure A.1: annualised real growth rates, 1966-2006, selected countries

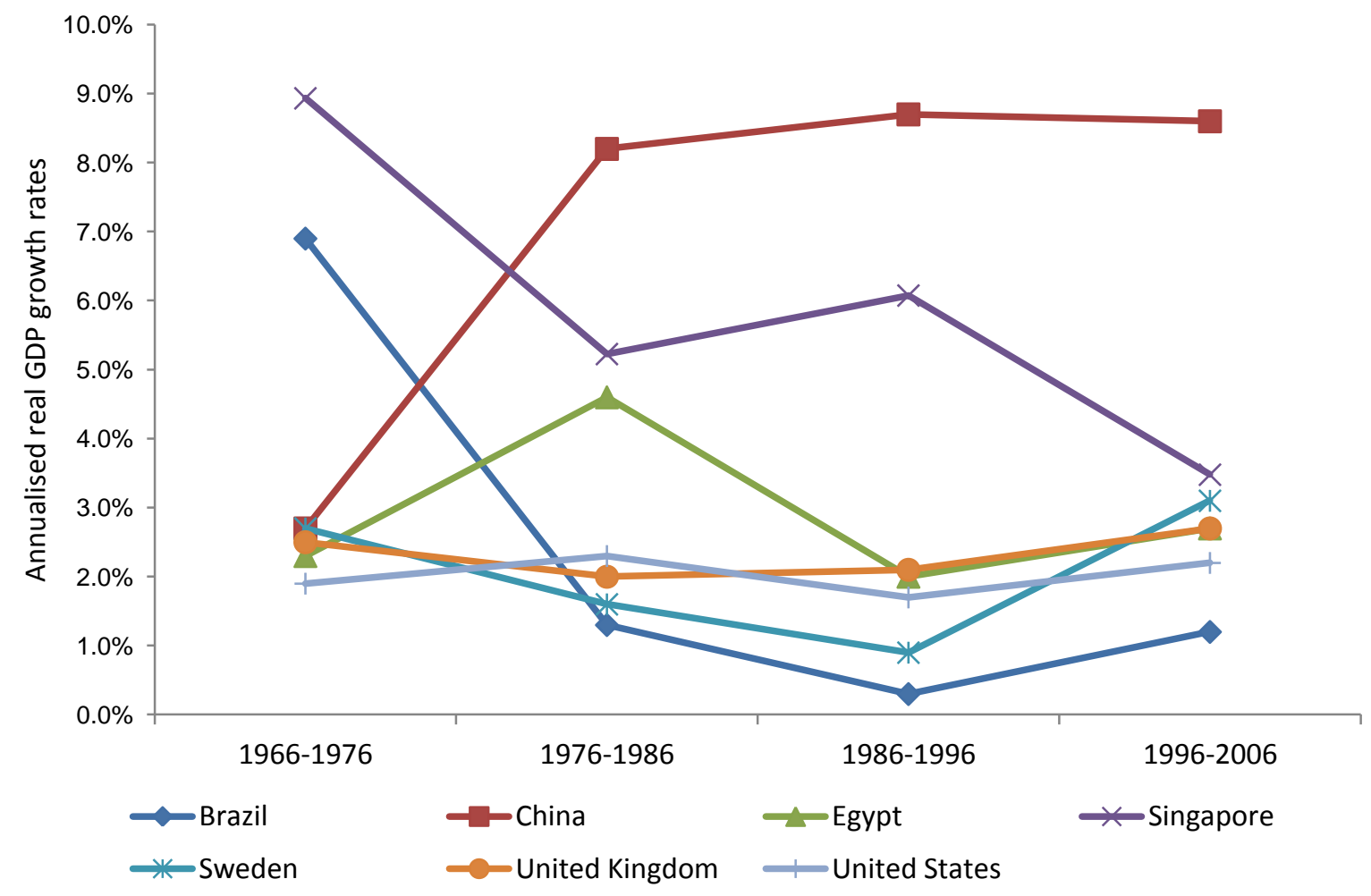


Table A.1: $\quad$ Country long-run growth rates and educational attainment, 1966-2006

\begin{tabular}{|c|c|c|c|c|c|c|c|}
\hline & $\begin{array}{c}\text { Annualised } \\
\text { growth rate, } \\
1966-2006\end{array}$ & $\begin{array}{c}\text { Years of } \\
\text { primary } \\
\text { education, } \\
1966\end{array}$ & $\begin{array}{c}\text { Years of } \\
\text { secondary } \\
\text { education, } \\
1966\end{array}$ & $\begin{array}{c}\text { Years of } \\
\text { tertiary } \\
\text { education, } \\
1966\end{array}$ & $\begin{array}{l}\text { Change in } \\
\text { years of } \\
\text { primary } \\
\text { education, } \\
\text { 1966-2006 }\end{array}$ & $\begin{array}{l}\text { Change in } \\
\text { years of } \\
\text { secondary } \\
\text { education, } \\
\text { 1966-2006 }\end{array}$ & $\begin{array}{l}\text { Change in } \\
\text { years of } \\
\text { tertiary } \\
\text { education, } \\
1966-2006\end{array}$ \\
\hline Algeria & 0.016 & 0.80 & 0.26 & 0.01 & 3.72 & 2.68 & 0.24 \\
\hline Argentina & 0.011 & 4.97 & 0.85 & 0.12 & 1.50 & 1.55 & 0.14 \\
\hline Australia & 0.021 & 5.52 & 3.54 & 0.55 & 0.40 & 1.40 & 0.46 \\
\hline Austria & 0.026 & 3.38 & 1.68 & 0.07 & 0.44 & 3.36 & 0.38 \\
\hline Bangladesh & 0.013 & 0.95 & 0.28 & 0.01 & 2.09 & 1.77 & 0.10 \\
\hline Barbados & 0.019 & 5.01 & 1.62 & 0.04 & 0.83 & 1.81 & 0.05 \\
\hline Belgium & 0.024 & 5.42 & 1.57 & 0.19 & 0.14 & 2.50 & 0.66 \\
\hline Belize & 0.033 & 6.44 & 0.90 & 0.19 & 0.89 & 0.87 & 0.05 \\
\hline Benin & 0.006 & 0.60 & 0.16 & 0.01 & 1.61 & 1.17 & 0.06 \\
\hline Bolivia & 0.001 & 2.46 & 1.04 & 0.10 & 3.75 & 1.68 & 0.32 \\
\hline Botswana & 0.068 & 1.43 & 0.10 & 0.00 & 4.64 & 2.97 & 0.10 \\
\hline Brazil & 0.024 & 1.69 & 0.64 & 0.05 & 3.45 & 1.19 & 0.15 \\
\hline Burundi & 0.003 & 0.74 & 0.05 & 0.00 & 1.71 & 0.34 & 0.02 \\
\hline Cameroon & 0.007 & 1.18 & 0.25 & 0.01 & 2.93 & 1.33 & 0.05 \\
\hline Canada & 0.020 & 5.42 & 2.78 & 0.46 & 0.43 & 2.18 & 0.86 \\
\hline Central African & -0.010 & 0.51 & 0.11 & 0.00 & 1.96 & 0.87 & 0.05 \\
\hline Chile & 0.027 & 4.22 & 1.34 & 0.09 & 1.18 & 2.32 & 0.56 \\
\hline China & 0.070 & 2.34 & 0.41 & 0.03 & 2.58 & 2.10 & 0.17 \\
\hline Colombia & 0.020 & 2.67 & 0.70 & 0.06 & 1.52 & 1.88 & 0.22 \\
\hline Dem. Rep. Congo & -0.031 & 0.88 & 0.08 & 0.00 & 1.63 & 0.85 & 0.03 \\
\hline Rep. of Congo & 0.015 & 1.26 & 0.36 & 0.02 & 2.52 & 1.74 & 0.03 \\
\hline Costa Rica & 0.022 & 3.51 & 0.52 & 0.09 & 1.81 & 1.74 & 0.38 \\
\hline Cote d'Ivoire & -0.005 & 0.73 & 0.27 & 0.03 & 2.21 & 0.88 & 0.09 \\
\hline Denmark & 0.020 & 6.06 & 1.89 & 0.28 & 0.30 & 1.05 & 0.29 \\
\hline Dominican Republic & 0.032 & 2.67 & 0.64 & 0.03 & 1.77 & 1.56 & 0.34 \\
\hline Ecuador & 0.016 & 3.24 & 0.59 & 0.05 & 1.55 & 1.82 & 0.40 \\
\hline Egypt & 0.029 & 0.70 & 0.28 & 0.07 & 2.98 & 2.33 & 0.24 \\
\hline El Salvador & 0.009 & 1.99 & 0.34 & 0.03 & 3.72 & 0.99 & 0.27 \\
\hline Fiji & 0.020 & 4.66 & 0.39 & 0.07 & 1.82 & 2.16 & 0.27 \\
\hline Finland & 0.028 & 5.20 & 0.92 & 0.15 & 0.53 & 2.37 & 0.60 \\
\hline France & 0.022 & 3.73 & 0.80 & 0.11 & 0.87 & 3.93 & 0.44 \\
\hline Gabon & 0.010 & 1.02 & 0.35 & 0.04 & 3.57 & 2.39 & 0.28 \\
\hline Gambia & 0.005 & 0.31 & 0.20 & 0.01 & 1.44 & 1.07 & 0.04 \\
\hline Ghana & 0.004 & 1.44 & 0.78 & 0.01 & 2.46 & 2.00 & 0.07 \\
\hline Greece & 0.026 & 4.49 & 1.83 & 0.10 & 1.21 & 1.56 & 0.70 \\
\hline Guatemala & 0.012 & 1.28 & 0.23 & 0.02 & 1.81 & 0.59 & 0.06 \\
\hline Guyana & 0.010 & 4.42 & 0.78 & 0.02 & 0.76 & 2.62 & -0.01 \\
\hline Honduras & 0.012 & 1.81 & 0.31 & 0.02 & 3.16 & 1.37 & 0.16 \\
\hline Hong Kong & 0.046 & 3.75 & 1.82 & 0.14 & 1.27 & 2.61 & 0.28 \\
\hline Hungary & 0.028 & 7.06 & 0.43 & 0.12 & 0.86 & 2.66 & 0.36 \\
\hline Iceland & 0.025 & 5.21 & 1.21 & 0.13 & 0.47 & 2.45 & 0.64 \\
\hline India & 0.030 & 1.08 & 0.18 & 0.03 & 1.99 & 1.28 & 0.12 \\
\hline Indonesia & 0.040 & 1.95 & 0.21 & 0.01 & 2.31 & 1.19 & 0.06 \\
\hline Iran & 0.016 & 1.02 & 0.37 & 0.03 & 3.14 & 3.08 & 0.43 \\
\hline Israel & 0.026 & 5.00 & 2.63 & 0.36 & 1.37 & 1.24 & 0.68 \\
\hline Italy & 0.025 & 4.06 & 1.11 & 0.07 & 0.57 & 3.11 & 0.23 \\
\hline Japan & 0.030 & 5.41 & 2.26 & 0.15 & 0.44 & 2.07 & 0.93 \\
\hline Kenya & 0.011 & 1.55 & 0.15 & 0.01 & 4.31 & 1.01 & 0.07 \\
\hline Korea & 0.058 & 4.04 & 1.31 & 0.12 & 1.66 & 3.45 & 0.89 \\
\hline Latvia & 0.032 & 3.17 & 1.65 & 0.22 & 1.85 & 3.00 & 0.31 \\
\hline Lesotho & 0.024 & 3.17 & 0.06 & 0.00 & 1.85 & 0.93 & 0.04 \\
\hline Liberia & -0.030 & 0.66 & 0.23 & 0.03 & 1.95 & 1.13 & 0.24 \\
\hline Luxembourg & 0.032 & 5.20 & 1.75 & 0.17 & 0.28 & 2.13 & 0.32 \\
\hline Malaysia & 0.039 & 2.60 & 0.68 & 0.04 & 2.60 & 3.46 & 0.30 \\
\hline Mauritania & 0.004 & 1.51 & 0.09 & 0.01 & 1.74 & 0.68 & 0.05 \\
\hline Mexico & 0.018 & 2.64 & 0.46 & 0.06 & 2.44 & 2.38 & 0.42 \\
\hline Morocco & 0.024 & 0.39 & 0.29 & 0.02 & 2.05 & 1.42 & 0.23 \\
\hline Nepal & 0.012 & 0.17 & 0.09 & 0.01 & 2.14 & 0.90 & 0.07 \\
\hline Netherlands & 0.023 & 5.72 & 1.47 & 0.13 & 0.00 & 2.89 & 0.60 \\
\hline Nicaragua & -0.009 & 2.05 & 0.46 & 0.10 & 1.62 & 1.50 & 0.34 \\
\hline Niger & -0.018 & 0.36 & 0.04 & 0.01 & 0.83 & 0.29 & 0.02 \\
\hline Norway & 0.029 & 6.87 & 1.01 & 0.13 & -0.30 & 4.03 & 0.60 \\
\hline Pakistan & 0.024 & 0.86 & 0.48 & 0.03 & 1.81 & 1.59 & 0.15 \\
\hline Panama & 0.018 & 3.75 & 0.99 & 0.10 & 1.61 & 2.28 & 0.57 \\
\hline Papua New Guinea & 0.003 & 0.72 & 0.23 & 0.00 & 2.65 & 0.28 & 0.04 \\
\hline Paraguay & 0.016 & 3.10 & 0.54 & 0.05 & 1.93 & 1.94 & 0.05 \\
\hline Peru & 0.006 & 3.06 & 0.78 & 0.12 & 1.95 & 2.23 & 0.54 \\
\hline Philippines & 0.012 & 3.64 & 0.83 & 0.27 & 1.73 & 1.44 & 0.71 \\
\hline Portugal & 0.032 & 2.97 & 0.45 & 0.04 & 2.11 & 1.80 & 0.23 \\
\hline Rwanda & 0.012 & 0.84 & 0.08 & 0.00 & 2.33 & 0.33 & 0.03 \\
\hline Senegal & -0.002 & 1.83 & 0.17 & 0.01 & 1.84 & 0.75 & 0.07 \\
\hline Sierra Leone & -0.001 & 0.49 & 0.17 & 0.01 & 1.91 & 0.78 & 0.03 \\
\hline
\end{tabular}




\begin{tabular}{|c|c|c|c|c|c|c|c|}
\hline Singapore & 0.059 & 2.90 & 1.36 & 0.06 & 2.12 & 1.54 & 0.49 \\
\hline South Africa & 0.006 & 3.44 & 0.99 & 0.07 & 2.26 & 1.42 & 0.08 \\
\hline Spain & 0.026 & 3.02 & 0.56 & 0.07 & 2.14 & 3.28 & 0.65 \\
\hline Sri Lanka & 0.033 & 4.30 & 0.80 & 0.01 & 1.88 & 3.36 & 0.45 \\
\hline Sudan & 0.014 & 0.46 & 0.12 & 0.02 & 1.91 & 0.49 & 0.05 \\
\hline Sweden & 0.021 & 5.32 & 2.11 & 0.20 & 0.52 & 2.79 & 0.57 \\
\hline Syria & 0.025 & 1.43 & 0.25 & 0.03 & 2.39 & 0.66 & 0.06 \\
\hline Thailand & 0.045 & 3.48 & 0.28 & 0.03 & 1.47 & 1.26 & 0.30 \\
\hline Togo & -0.002 & 0.55 & 0.05 & 0.00 & 3.14 & 1.62 & 0.06 \\
\hline Trinidad and Tobago & 0.022 & 5.23 & 0.73 & 0.03 & 1.37 & 1.85 & 0.09 \\
\hline Tunisia & 0.031 & 0.90 & 0.36 & 0.03 & 3.14 & 1.91 & 0.23 \\
\hline Turkey & 0.025 & 1.67 & 0.38 & 0.03 & 2.57 & 1.62 & 0.21 \\
\hline United Kingdom & 0.023 & 5.27 & 1.42 & 0.14 & 0.33 & 1.67 & 0.51 \\
\hline United States & 0.020 & 5.57 & 3.92 & 0.54 & 0.38 & 1.55 & 0.95 \\
\hline Uruguay & 0.014 & 4.07 & 1.00 & 0.11 & 1.45 & 1.22 & 0.15 \\
\hline Venezuela & -0.003 & 2.75 & 0.54 & 0.06 & 1.75 & 0.96 & 0.33 \\
\hline Zambia & -0.011 & 2.51 & 0.05 & 0.01 & 2.77 & 1.11 & 0.03 \\
\hline Zimbabwe & -0.002 & 2.22 & 0.45 & 0.06 & 3.07 & 1.72 & -0.04 \\
\hline
\end{tabular}


To improve the robustness of the result in section 5.3, I use later measures of educational attainment of the workforce - recorded in 1985 and 2005. Data might be more accurate in recent years, compared to what has been derived by Barro and Lee for the 1960s. Moreover, later measures might better reflect changes in policy during the time period. I also look at shorter time periods. Table A.x shows these results. Columns (1) and (2) show the results for the later measures. Column (3) to (6) show the results for ten year time periods starting in 1966-1976 and finishing in 1996-2006. There is no indication in these results that higher education is related to economic growth.

Table A.2 Economic growth and types of schooling in the OECD, alternative education measures

\begin{tabular}{lcccccc}
\hline & $(1)$ & $(2)$ & $(3)$ & $(4)$ & $(5)$ & $(6)$ \\
\cline { 2 - 7 } Initial GDP/capita & -0.0010 & $-0.0011^{* *}$ & -0.0007 & -0.0001 & -0.0005 & -0.0003 \\
& $(0.107)$ & $(0.044)$ & $(0.489)$ & $(0.862)$ & $(0.466)$ & $(0.439)$ \\
Years of schooling, & $0.0045^{* * *}$ & $0.0036^{* *}$ & 0.00426 & $0.0035^{*}$ & $0.0072^{* * *}$ & 0.0014 \\
primary & $(0.001)$ & $(0.016)$ & $(0.231)$ & $(0.090)$ & $(0.016)$ & $(0.522)$ \\
& & & & \\
Years of schooling, & $0.0076^{* *}$ & $0.0071^{* * *}$ & 0.0092 & $0.0106^{*}$ & 0.0080 & 0.0040 \\
secondary & $(0.015)$ & $(0.001)$ & $(0.291)$ & $(0.089)$ & $(0.235)$ & $(0.293)$ \\
& -0.0211 & -0.0020 & -0.0475 & $-0.0667^{*}$ & -0.0298 & -0.0012 \\
Years of schooling, & $(0.156)$ & $(0.805)$ & $(0.037)$ & $(0.060)$ & $(0.334)$ & $(0.939)$ \\
tertiary & 0.0044 & $0.0121^{* *}$ & $0.0217^{* * *}$ & -0.0065 & $0.0206 * * *$ & 0.0096 \\
& $(0.324)$ & $(0.044)$ & $(0.000)$ & $(0.264)$ & $(0.003)$ & $(0.206)$ \\
Constant & 91 & 91 & 91 & 91 & 91 & 91 \\
& 0.267 & 0.323 & 0.044 & 0.135 & 0.130 & 0.043 \\
\hline $\mathrm{N}$ & & & & & & \\
$\mathrm{R}^{2}$ &
\end{tabular}

Source: World Bank data. Dependent variable: (1)-(2) real GDP growth 1966-2006; (3) real GDP growth 19661976; (4) real GDP growth 1976-1986; (5) real GDP growth 1986-1996; (6) real GDP growth 1996-2006. Average years of schooling: (1) 1985; (2) 2005; (3) 1965; (4) 1975; (5) 1985; (6) 1995 Note: GDP/capita is measured in 1000s. $*, * *$ and $* * *$ denote significance at the $90 \%, 95 \%$ and $99 \%$ level respectively. P-values in parentheses. 
Table A.3: Growth in graduates by subject, 1994/5 to 2010/11.

Subject

Mass communication

Subjects Allied to Medicine

Biological Sciences

Creative Arts \& Design

Business \& Administrative Studies

Veterinary Science

Social, Economic \& Political Studies

Law

Computer Science

Medicine \& Dentistry

Mathematical Sciences

Humanities

Languages

Agriculture \& Related Subjects

Architecture, Building \& Planning

Education

Physical Sciences

Engineering \& Technology

All UK HE Institutions
Annualised growth rate of qualifications obtained

$9.7 \%$

$7.2 \%$

$6.5 \%$

$6.3 \%$

$4.9 \%$

$3.9 \%$

$3.8 \%$

$3.6 \%$

$3.6 \%$

$3.5 \%$

$3.4 \%$

$3.3 \%$

$2.2 \%$

$2.0 \%$

$1.7 \%$

$1.2 \%$

$0.6 \%$

$0.2 \%$

$2.8 \%$

\section{Source: HESA}

